\title{
Change in microvascular endothelial function after initiating class III antiarrhythmic medications in atrial fibrillation patients
}

\author{
Laith Alkukhun ${ }^{1}$, Samuel Sauerwein ${ }^{1}$, Amr Barakat ${ }^{2}$, Dylan Burbee ${ }^{1}$, Adam Straub ${ }^{1}$, Steve \\ Reis $^{1}$, Oladipupo olafiranye ${ }^{1}$, Cameron Dezfulian ${ }^{1}$, and Samir Saba ${ }^{2}$ \\ ${ }^{1}$ University of Pittsburgh Medical Center \\ ${ }^{2}$ University of Pittsburgh
}

July 29, 2020

The endothelium plays a critical role in determining vascular tone. Endothelial dysfunction is characterized by an imbalance between endothelium derived vasodilating and vasoconstricting effects (1). Forearm artery endothelial function measured non-invasively is commonly used as a surrogate marker for endothelial function of the coronary arterial circulation (2) and has been used to assess the effect of atrial fibrillation on peripheral arterial function. Studies have demonstrated that atrial fibrillation is associated with endothelial dysfunction of forearm arteries, which improves after successful electrical cardioversion (3) or catheter ablation (4). Measurements of endothelial function have often focused on flow within the larger conduit arteries as opposed to the microcirculation. Most studies used post occlusive reactive hyperemia (PORH) or flow mediated dilation which are in part nitric oxide (NO)-dependent. Microcirculatory endothelial function following AF treatment has not been studied.

Laser speckle contrast imaging (LSCI) is a technology that measures blood flow in the skin microvasculature using laser beam light that reflects off moving red blood cells (5). Iontophoresis is a method for non-invasive transdermal drug delivery to the skin microvasculature based on the transfer of charged molecules using a low-intensity electric current (5). We hypothesized that the microvascular endothelial function in AF patients improves after sustaining normal sinus rhythm using antiarrhythmic drugs (AAD). We utilized LSCI to measure change in blood perfusion after brief ischemia-reperfusion (post-occlusive RH [PORH]) and used iontophoresis to transfer vasodilating agents to the skin microcirculation (chemical RH).

This prospective cohort study was approved by the University of Pittsburgh Institutional Review Board. All subjects provided written informed consents. We recruited patients with symptomatic AF electively admitted to the inpatient cardiac electrophysiology service for initiation of sotalol or dofetilide. Measurements were repeated during follow up outpatient visits after hospital discharge. Exclusion criteria included age above 75 years old, history of clinical cardiovascular disease, advanced organ failure, major trauma within the preceding 3 months, uncontrolled autoimmune disease, or inflammatory disease.

Prior to attaching electrodes, the forearm was gently cleaned with alcohol wipes. The dispersive electrode was attached proximal to the wrist. The drug delivery electrode was attached $10-15 \mathrm{~cm}$ from the radial styloid process. Patients were kept in a supine position during the test. After laying down for 15 minutes, their endothelium-dependent vasodilation was assessed using iontophoresis (Perimed Perilont, Järfälla, Sweden) to transmit acetylcholine $1 \%$. Next, we used iontophoresis to transmit sodium nitroprusside $2.5 \%$ for the purpose of evaluating the endothelium independent vasodilation. Afterwards, PORH was acquired as a measure of overall vascular function. To this end, we inflated a blood pressure cuff around the patient's arm to $50 \mathrm{mmHg}$ above systolic blood pressure and deflated the cuff after 5 minutes. The LSCI camera (Perimed PeriScan, Järfälla, Sweden) was placed $20 \mathrm{~cm}$ above the forearm. Resting flow (RF) was obtained for 1 minute. Peak flow $(\mathrm{PF})$ was obtained for 2 minutes after iontophoresis and after deflating the blood pressure 
cuff (post-occlusive RH). We recorded resting flow (RF), peak flow (PF) and calculated RH [(PF-RF)/RF].

We enrolled 12 patients with a median age of 69 (65-70) years (33\% men). Patients had a median BMI of $34(28-36) \mathrm{kg} / \mathrm{m}^{2}$ and a median CHADVASC score of 3 (IQR 2-3). Twenty five percent of patients had paroxysmal atrial fibrillation. Three patients had moderate to severe LA dilation. Half of the patients were started on sotalol and the other half on dofetilide, as per the choice of the treating electrophysiologist. We conducted this study between July 2019 and June 2020, during which time seven patients had AF recurrence. Two patients with AF recurrence underwent pulmonary vein isolation and their AADs was discontinued. Two other patients were scheduled to undergo ablation but their AADs were continued. Three patients had decreased burden of their symptoms despite recurrence and their AADs were continued.

As shown in Table 1, patients with or without recurrence of AF had no significant change in chemical RH or PORH after treatment. RH before starting AADs was not significantly different between patients who had AF recurrence and patients who did not. Patients on sotalol had similar RH to patients to the other study patients at time of follow up.

In summary, we found that microvascular endothelial NO dependent function, endothelial NO independent function and PORH did not change in AF patients after the initiation of class III AADs. This was true regardless of whether normal sinus rhythm was maintained or not and for both AADs used. Our study has limitations. The small number of patients limits the statistical power of the data. Also, no continuous heart rhythm monitoring was used in our cohort. Alteration of endothelium derived vasoactive substances, other than $\mathrm{NO}$, in AF requires additional studies. Notwithstanding these limitations, an important finding of this research suggests that atrial fibrillation's effect on the microcirculation is different from its effect on the larger conduit arteries.

\section{References:}

1. Flammer AJ, Anderson T, Celermajer DS, Creager MA, Deanfield J, Ganz P, et al. The assessment of endothelial function: From research into clinical practice. Circulation. 2012;

2. Sax FL, Cannon RO, Hanson C, Epstein SE. Impaired Forearm Vasodilator Reserve in Patients with Microvascular Angina. N Engl J Med. 1987;

3. Skalidis EI, Zacharis EA, Tsetis DK, Pagonidis K, Chlouverakis G, Yarmenitis S, et al. Endothelial Cell Function During Atrial Fibrillation and After Restoration of Sinus Rhythm. Am J Cardiol. 2007;

4. Shin SY, Na JO, Lim HE, Choi CU, Choi J Il, Kim SH, et al. Improved endothelial function in patients with atrial fibrillation through maintenance of sinus rhythm by successful catheter ablation. J Cardiovasc Electrophysiol. 2011;

5. Roustit M, Cracowski JL. Non-invasive Assessment of Skin Microvascular Function in Humans: An Insight Into Methods. Microcirculation. 2012.

Table 1:

\begin{tabular}{llll}
\hline & $\begin{array}{l}\text { Before treatment } \\
\text { Median }(\mathrm{IQR})\end{array}$ & $\begin{array}{l}\text { At time of follow up* } \\
\text { Median }(\mathrm{IQR})\end{array}$ & P value** \\
\hline Ach peak flow, PUs & $138(125,151)$ & $138.5(119.5,146.5)$ & $0.72(\mathrm{n}=11)$ \\
Ach RH, \% & $154(147,207)$ & $149(149,194)$ & $0.06(\mathrm{n}=11)$ \\
SNP peak flow, PUs & $125(113,126)$ & $136.5(127,143)$ & $0.14(\mathrm{n}=9)$ \\
SNP RH, \% & $160(151,177)$ & $144(136,228)$ & $0.86(\mathrm{n}=9)$ \\
$\begin{array}{l}\text { Post occlusive peak } \\
\text { flow, PUs }\end{array}$ & $103(97,108)$ & $142(104,134)$ & $0.07(\mathrm{n}=8)$ \\
PORH, \% & $119(109,132)$ & $133(116,153)$ & $0.12(\mathrm{n}=8)$
\end{tabular}




\begin{tabular}{|c|c|c|c|}
\hline & $\begin{array}{l}\text { Before treatment } \\
\text { Median (IQR) }\end{array}$ & $\begin{array}{l}\text { At time of follow up* } \\
\text { Median (IQR) }\end{array}$ & $\mathbf{P}$ value** \\
\hline $\begin{array}{l}\text { Measurements before } \\
\text { treatment }\end{array}$ & $\begin{array}{l}\text { AF patients with } \\
\text { recurrence Median } \\
\text { (IQR) }\end{array}$ & $\begin{array}{l}\text { AF patients with no } \\
\text { recurrence Median } \\
\text { (IQR) }\end{array}$ & $\mathbf{P}$ value $* * *$ \\
\hline Ach peak flow, PUs & $121(118,121)$ & $138(134,145)$ & $0.76(n=12)$ \\
\hline Ach RH, \% & $141(119,141)$ & $196(162,200)$ & $0.64(n=12)$ \\
\hline SNP peak flow, PUs & $122(115,124)$ & $120(115,125)$ & $1.00(n=10)$ \\
\hline SNP RH, $\%$ & $135(115,152)$ & $173(156,179)$ & $0.11(n=10)$ \\
\hline $\begin{array}{l}\text { Post occlusive peak } \\
\text { flow, PUs }\end{array}$ & $101(98,103)$ & $104(94,107)$ & $1.00(\mathrm{n}=9)$ \\
\hline PORH, $\%$ & $116(101,119)$ & $129(127,142)$ & $0.11(n=9)$ \\
\hline $\begin{array}{l}\text { (Measurements at } \\
\text { time of follow up - } \\
\text { before treatment) }\end{array}$ & $\begin{array}{l}\text { AF patients with } \\
\text { recurrence Median } \\
\text { (IQR) }\end{array}$ & $\begin{array}{l}\text { AF patients with no } \\
\text { recurrence Median } \\
\text { (IQR) }\end{array}$ & $\mathbf{P}$ value $* * *$ \\
\hline Change in Ach RH, \% & $-2(-23,+17)$ & $-23(-33,-16)$ & $0.42(\mathrm{n}=11)$ \\
\hline $\begin{array}{l}\text { Change in SNP RH at } \\
\text { time of follow up, } \%\end{array}$ & $-4(-25,+16)$ & $-10(-29,+23)$ & $0.90(\mathrm{n}=9)$ \\
\hline $\begin{array}{l}\text { Change in PORH at } \\
\text { time of follow up, } \%\end{array}$ & $+22(+18,+24)$ & $+14(+11,+14)$ & $1.00(\mathrm{n}=8)$ \\
\hline $\begin{array}{l}\text { (Measurements at } \\
\text { time of follow up - } \\
\text { before treatment) }\end{array}$ & $\begin{array}{l}\text { AF patients on sotalol } \\
\text { Median (IQR) }\end{array}$ & $\begin{array}{l}\text { AF patient not on } \\
\text { sotalol Median (IQR) }\end{array}$ & $\mathbf{P}$ value $* * *$ \\
\hline Change in Ach RH, \% & $-31(-37,-31)$ & $-16(-22,+15)$ & $0.25(\mathrm{n}=11)$ \\
\hline $\begin{array}{l}\text { Change in SNP RH at } \\
\text { time of follow up, } \%\end{array}$ & $-10(-23,-4)$ & $-4(-33,+54)$ & $0.90(\mathrm{n}=9)$ \\
\hline $\begin{array}{l}\text { Change in PORH at } \\
\text { time of follow up, } \%\end{array}$ & $+22(-10,+24)$ & $+14(+14,+25)$ & $0.79(\mathrm{n}=8)$ \\
\hline
\end{tabular}

Abbreviations: Ach: acetylcholine, PUs: perfusion units, SNP: sodium nitroprusside, IQR: interquartile range.

${ }^{*}$ Two patients had their dofetilide discontinued after undergoing an ablation procedure.

** Related-Samples Wilcoxon Signed Rank Test.

*** Independent- Samples Mann- Whitney U Test. 